\title{
Isolation and Culture of Lycopersicon esculentum Root Protoplasts
}

\author{
Shigeru Imanishi, Jun Momose and Iwao Hiura \\ Department of Horticulture, Faculty of Agriculture, Yamagata University, \\ 1-23, Wakaba-cho, Tsuruoka, Yamagata, Japan 997
}

(Received October 12, 1984)

(Accepted November 20, 1984)

In recent years, the isolation of root protoplasts of germinating seeds in higher plants has become a comparatively easy task. ${ }^{1-5)}$ Cell division and colony formation from root protoplasts have been induced in some plants ${ }^{2-5)}$ and regeneration to complete plants was achieved in Brassica and Medicago. ${ }^{3,4)}$ Root protoplasts are an attractive source because of the uniformity and ease of production of experimental materials and because they provide a colourless partner for pigmented protoplasts in fusion experiments. ${ }^{1,4)}$ Furthermore, protoplasts derived from roots are thought to have the advantage of chromosome number stability compared with those from cultured cells.

The present report describes the isolation of Lycopersicon esculentum root protoplasts from germinating seeds and the first successful induction of cell division and colony formation from the protoplasts.

L. esculentum L. cv. Kyoryoku Toko was used as a material. One hundred eighty root tips of 5 to $8 \mathrm{~mm}$ were excised about half a day after germination, and, without being cut into segments, were plasmolyzed for one hour in CPW 9M solution. ${ }^{6)}$ The plasmolyzed root tips were incubated in an enzyme solution containing $2 \%$ cellulase "Onozuka" R10 and $0.6 \%$ pectolyase Y-23 in the CPW 9M solution. After the enzyme treatment for $6 \mathrm{hr}$, the root tips were gently teased with a dissection needle and the released protoplasts were filtered through a sieve and washed three times in the CPW 9M solution. Yields of root protoplasts were approximately $1.5 \times 10^{6}$ per 200 root tips before washing, but afterwards were reduced to about $4 \times 10^{5}$ per 200 root tips. Root protoplasts after washing were plated in a B5 medium $^{7}$ ) solidified with $0.4 \%$ agar, which contained $1.0 \mathrm{mg} / l 2,4-\mathrm{D}, 0.5 \mathrm{mg} / l \mathrm{NAA}, 0.5 \mathrm{mg} / l \mathrm{BA}$, and $7 \%$ mannitol. Plating density was $5.0 \times 10^{4}$ protoplasts per $\mathrm{ml}$ and each dish contained $1 \times 10^{5}$ protoplasts. Dishes were incubated at $29^{\circ} \mathrm{C}$ in darkness. The initiation of cell division was observed on the fourth day after incubation, but the growth of colony was relatively slow (Figs. 1 and 2). The percentage of cell division on the 25th day was estimated to be $14.6 \%$, with a colony size of 100 to $200 \mu \mathrm{m}$ in diameter (Fig. 3). Colony formation was examined on the 50th day. The number of colonies larger than $300 \mu \mathrm{m}$ in diameter was estimated to be 950 per dish (Fig. 4).

In the present study it was found that a yield of tomato root protoplasts could be achieved at much the same level of Brassica, ${ }^{3)}$ although the enzymes used in our experiment were quite different from those used by Xu et al. ${ }^{2-5}$ ) It was also found that using the same medium as in the culture of tomato leaf protoplasts, ${ }^{8-10}$ ) cell division and colony formation from tomato root protoplasts could be induced to no less extent than those from tomato leaf protoplasts.

The authors express thanks to Mrs. E. Shiraiwa for her technical assistance. 


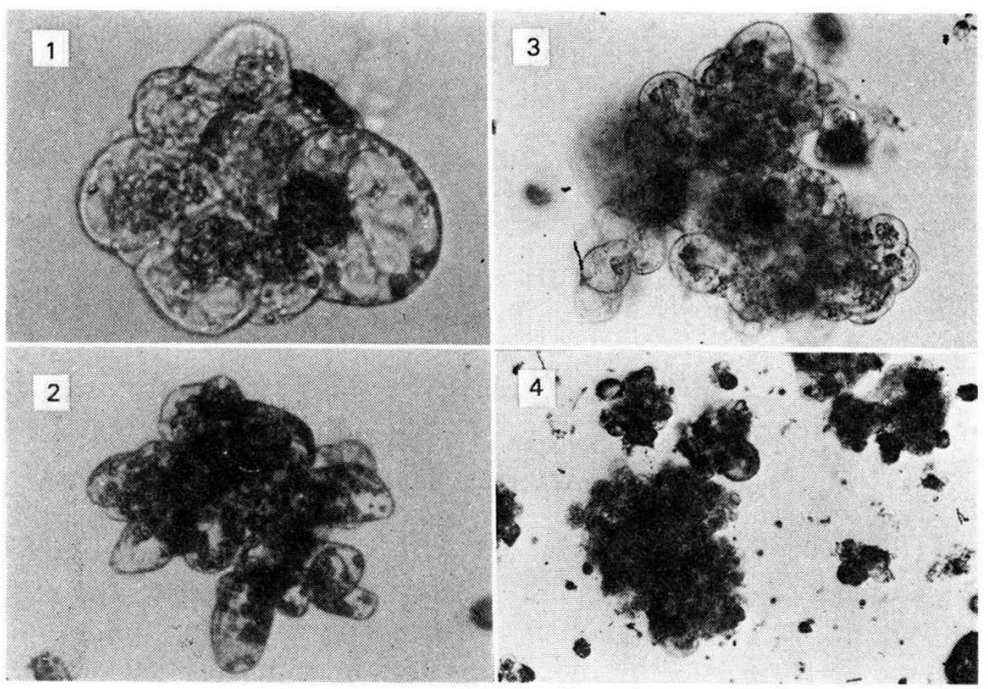

Figs. 1 and 2. Early stage of cell colony from tomato root protoplasts.

Fig. 3. Cell colony from tomato root protoplasts on the 25 th day after incubation.

Fig. 4. Cell colony from tomato root protoplasts on the 50th day after incubation.

\section{References}

1) Lin, W., 1980. Plant Physiol., 66: 550-554.

2) Xu, Z-H, M.R. Davey, E.C. Cocking, 1981. Z. Pflanzenphysiol., 104: 289-298.

3) Xu, Z-H, M.R. Davey, E.C. Cocking, 1982a. Plant Sci. Lett., 24: 117-121.

4) Xu, Z-H, M.R. Davey, E.C. Cocking, 1982b. Z. Pflanzenphysiol., 107: 231-235.

5) Xu, Z-H, M.R. Davey, E.C. Cocking, 1982c. Plant Sci. Lett., 24: 111-115.

6) Cocking, E.C., J.F. Peberdy, 1974. A Practical Handbook, University of Nottingham, Nottingham.

7) Gamborg, O.L., R.A. Miller, K. Ojima, 1968. Exp. Cell Res., 50: 151-158.

8) Zapata, F.J., P.K. Evans, J.B. Power, E.C. Cocking, 1977. Plant Sci. Lett., 8: 119-124.

9) Imanishi, S., I. Hiura, 1982. Bull. Yamagata Univ. (Agric. Sci.), 9(1): 111-119 (In Japanese).

10) Morgan, A., E.C. Cocking, 1982. Z. Pflanzenphysiol., 106: 97-104.

\section{《和文要約》}

\section{トマトの根プロトプラストの単離と培養 \\ 今西茂・百瀨 淳・樋浦 嚴 \\ 山形大学農学部園芸繁殖学研究室}

トマトの発芽根から根プロトプラストを単離するため, 品種 “強力東光” を用い, 発芽約半日目の根 をセルラーゼオノズカR $102 \%$ ，ペクトリアーゼY-23 $0.6 \%$ を含む高張液で， 6 時間振とう処理した. 処理後, 酵素を含まない高張液で 3 回洗浄した. 洗浄前のプロトプラスト収量は根 200 本当り約 $1.5 \times$ $10^{6}$ 個であったが, 洗浄後約 $4 \times 10^{5}$ 個汇減少した. 単離した根プロトプラストは 2,4-D $1.0 \mathrm{mg} / l, \mathrm{NAA}$ $0.5 \mathrm{mg} / l, \mathrm{BA} 0.5 \mathrm{mg} / l$, マニトール $7 \%$ を含む $\mathrm{B} 5$ の寒天培地に $5 \times 10^{4} / \mathrm{ml}$ の密度でプレートし, $29^{\circ} \mathrm{C}$ 暗黒下で培養した. 25 日目の分裂頻度は約 $15 \%$ であったた. 50 日目における $300 \mu \mathrm{m}$ 以上のコロニーは $1 \times 10^{5}$ プロトプラスト当り約 950 個えられた. 